\title{
THRUST ANALYSIS ON 250 WATTS DC MOTOR FOR LOCOMOTION BOAT
}

\author{
Rahmad Samosir $^{1}$, Melya Dyanasari Sebayang ${ }^{1}$, Medyawanti Pane ${ }^{1}$ and Alberto \\ Haryanto Silaban ${ }^{1} \mathbb{U}$ \\ ${ }^{1}$ Mechanical Engineering, Universitas Kristen Indonesia, Indonesia
}

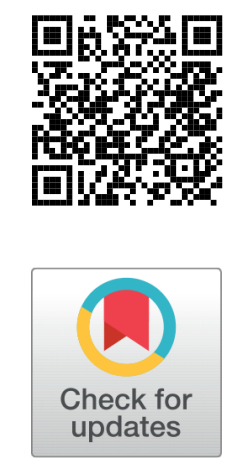

Received 6 July 2021

Accepted 16 July 2021

Published 31 July 2021

Corresponding Author

Rahmad Samosir, rahmad.samosir

@uki.ac.id

DOI $10.29121 /$

granthaalayah.v9.i7.2021.4093

Funding: This research received no specific grant from any funding agency in the public, commercial, or not-for-profit sectors.

Copyright: (C) 2021 The Author(s). This is an open access article distributed under the terms of the Creative Commons Attribution License, which permits unrestricted use, distribution, and reproduction in any medium, provided the original author and source are credited.

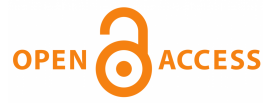

\section{ABSTRACT}

To make it easier for farmers in terms of maintenance and transportation of community-owned coconut and palm oil crops, the team tried to make a design for testing the thrust of a 250 Watt DC motor powered by solar heat for boat propulsion, by testing the boat propeller with variations in the diameter of the propeller $17.5 \mathrm{~mm}, 15 \mathrm{~mm}, 15.5 \mathrm{~mm}, 14.8 \mathrm{~mm}$, and $14.5 \mathrm{~mm}$, as well as testing with variations in driving rotation and variations in driving rotation with the number of gear teeth $11,16,20$, and 22 . From the calculation of the torque obtained is $1,090 \mathrm{Nmm}$ so that the diameter is obtained propeller is $5 \mathrm{~mm}$. Thrust force test results obtained vary depending on the diameter and variations of the rotation of the propeller drive so that an adequate diameter is obtained by using a diameter of $14.8 \mathrm{~mm}$ with a current of $9.2 \mathrm{~A}$ with a thrust of $7.5 \mathrm{kgf}$. Meanwhile, for an adequate variety of the driving speed, the number of teeth is 20 and the thrust is $7.5 \mathrm{kgf}$ and the current is 10 . This value meets the requirements because the current strength does not exceed $10 \mathrm{~A}$. From the test results, it can be concluded that the design and analysis are very fulfilling needs.

Keywords: Thrust, Propeller, Propeller Diameter

\section{INTRODUCTION}

The development of technology in the field of renewable energy is currently very advanced, especially by utilizing solar energy on ships. One example of the use of renewable energy to generate electricity using solar cells. The advantage of solar cell is that it is an energy generator that is environmentally friendly and does not cause pollution at all. It is very different from other energy sources, such as coal and fossil fuels which cause a lot of pollution, both air and water pollution. Elinur (2010)

Currently, in lowland areas, many coconut and oil palm farmers are engineeringcoconut and oil palm plantations such as designing trasportation wheels on peatlands where the peat soil that has been passed over and over again will experience 
compaction so that the land can be used for motorbikes to pass, and even better if filled with mortar, Samosir (2021) as well as by making a soil heap by making canals as shown in Figure 1. Making roads or canals on coconut and oil palm plantations so that canoes can be passed is easier for farmers in the care and transportation of community-owned coconut and oil palm harvests. However, the use of boats with fossil fuels will increase operational costs, while using solar-powered boats does not need to use fuel oil (fossil fuels), in terms of the cost of making boats with engines using fossil fuels compared to solar power can be said to be cheaper with Solar. In addition to cheaper costs, the use of solar cells is also environmentally friendly or does not cause air pollution.

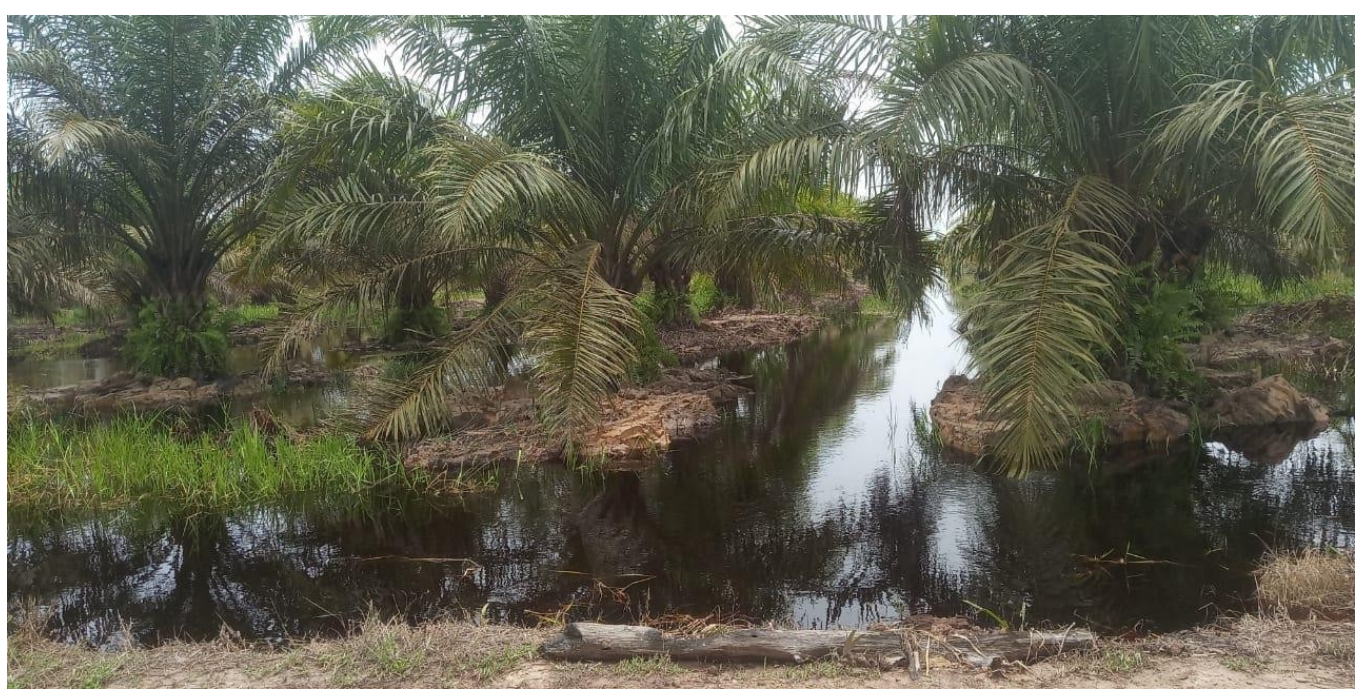

Figure 1 Coconut and Oil palm plantations on low land with ditches between plants.

\section{MATERIALS AND METHODS}

\section{Solar Cell}

A Solar cell is a power plant that has a working principle by converting or converting sunlight into an electric current. Previously, the use of solar cells or solar panels was not so much because the efficiency of solar cells was low compared to other sources, on the other hand, the initial cost for solar cells or solar cells was very large. However, the development of technology is very fast and sophisticated to turn solar cells into one of the popular energy sources in the future because the efficiency of solar cells will increase. Amin (2017)

\section{Thrust}

In the manufacture of boats/ships need to consider planning in the field of propulsion systems. The aspect of the propulsion system is planning a good propeller design in order to achieve the purpose of the boat/ship function in terms of speed as needed. The speed of the boat/ship can not be separated from a good propeller design in 


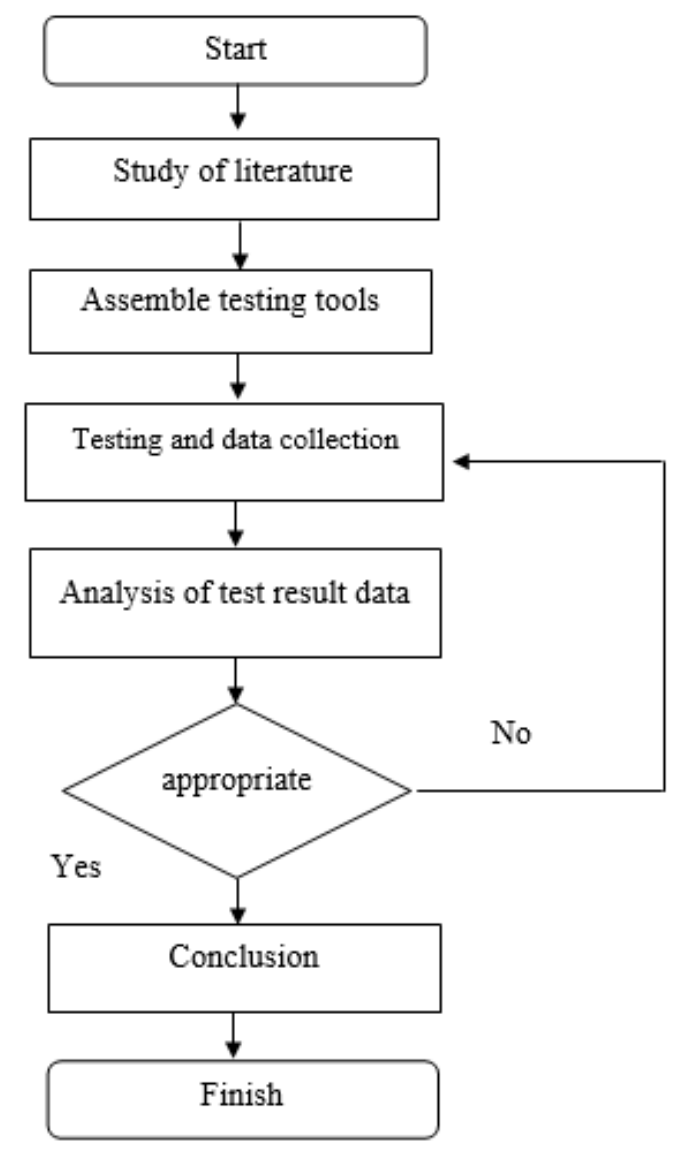

Figure 2 Flowchart

order to get the optimal thrust. Variations in the diameter of the propeller greatly affect the high thrust value generated by the workload of the ship, if the propeller is not made well, there will be a decrease in performance efficiency propeller. Rojali (2019) Calculation of thrust (Thrust), When a ship or boat moves forward, the propeller will accelerate with liquid fluid. This acceleration will increase the momentum of the water. Based on the second law of Newton's formula, states that the force equivalent to an increase in the acceleration of the momentum of water is called the thrust, or Thrust is the power that the propeller distributes to the water

$F s=6 \pi r \eta v$

It is expected that the thrust Fs generated by the propeller can be maximum, for that it is necessary to design a propeller with a better tilt angle and a precise manufacturing process so that the propulsion power supplied can be converted into trust (thrust force).

Power

The power obtained is from solar panels that convert sunlight energy into electrical energy, the energy produced is directly stored in the battery so that the current 
obtained is DC. The capacity of the solar panels used is adjusted to the needs in the field.

\section{Control System}

The design of the control system used is as follows:

1. The motor used in this test is a 250 watt 24 Volt DC motor to drive the propeller as boat propulsion, the propeller used in this test is a 2 leaf propeller, with a propeller diameter test with 4 diameter variations. This test is carried out in order to get the appropriate diameter of the propeller to be used and to get the maximum thrust.

2. Magnetic Circuit Breaker is to disconnect the power supply voltage source. If there is an overload or short circuit, the magnetic circuit breaker will automatically cut off the electricity to prevent a fire.

3. The system to regulate the rotational speed of the motor, namely the microcontroller. The microcontroller used in this test is a dimmer which functions to regulate the rotational speed of the motor.

4. This test uses 2 batteries, each battery has a voltage of 12 Volts, then the batteries are connected in series so that the battery output voltage becomes 24 Volts because the motor used in this test is a DC motor with a voltage of 24 Volts.

\section{Transmission system design}

This test is carried out in 2 variations, namely variations in the diameter of the propeller and variations in the rotational speed of the drive shaft.

1. The propeller used in this test is a propeller that has 2 leaves and variations in diameter, namely: $14.5 \mathrm{~cm}, 14.8 \mathrm{~cm}, 15.8 \mathrm{~cm}, 17.5 \mathrm{~cm}$.

2. Tests with variations in the rotational speed of the drive shaft are made by varying the number of teeth on the gear so that the output rotation can change, the variations in the number of teeth used are 11, 1620 , and 22 teeth.

3. Because the coupling used in this test is not sold in the market, the author uses a modified clutch so that the power transferred from one shaft to another is maximized.

\section{Thrust testing on propeller}

This test aims to test a 250 watt 24 Volt DC motor used as a boat propulsion so that it can be applied to a boat.

This test was carried out at the Mechanical Engineering Laboratory of the Christian University of Indonesia, by connecting the Propeller to a DC motor using a shaft, then tested using water that has been filled in the drum. 


\section{- Testing the propeller using a variation of diameter}

This test uses a propeller with 4 diameter variations, the step of this test is to connect the propeller shaft to the motor using a coupling so that the rotation of the propeller and the rotation of the motor will be the same. The schematic for this test is shown in Figure 3 .

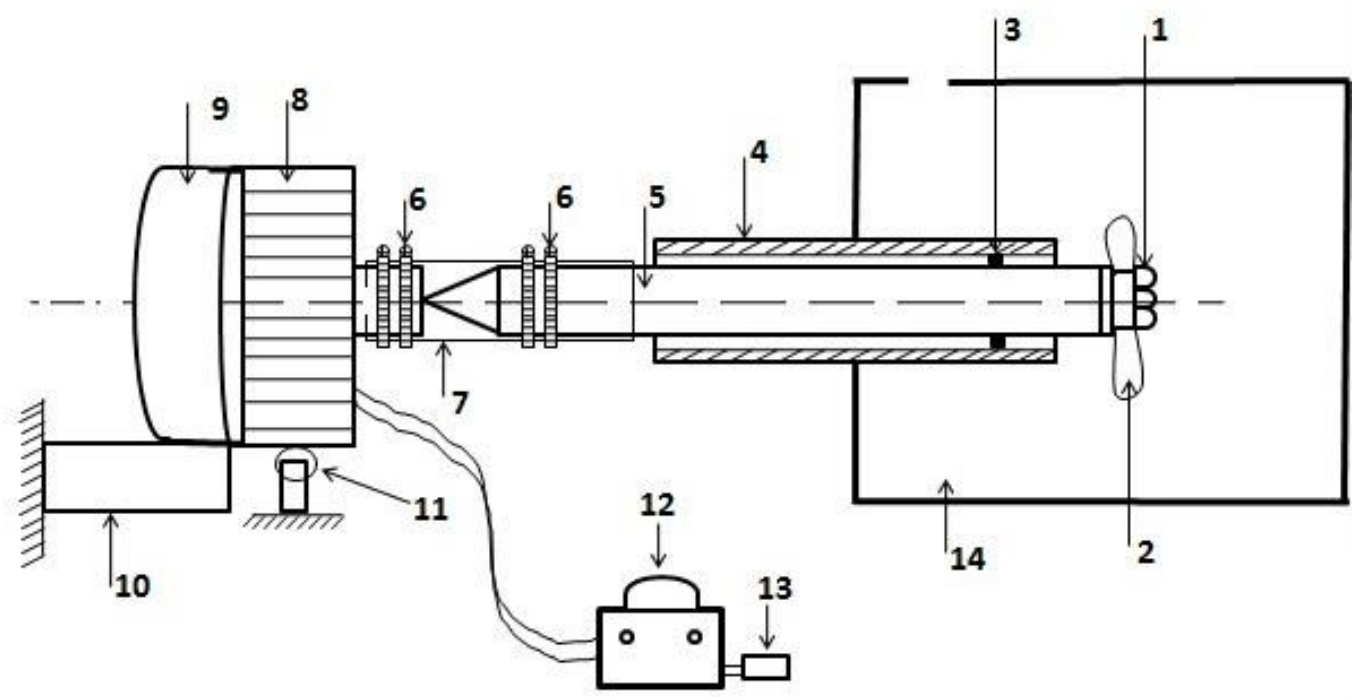

Figure 3 Schematic of Thrust Testing With Variations In Propeller Diameter

\section{Picture description:}

1. Fastening bolt

2. Propeller with variations of 4 sizes

3. Bearings

4. Shaft guard

5. Connecting shaft and coupling (cross joint)

6. Clamp (fastener)

7. Clutch or coupling

8. 24 Volt DC electric motor, with a power of 250 Watt

9. Scales for measuring propeller thrust

10. Scale holder

11. Motorcycle mount

12. Battery $12 \mathrm{~V}, 70 \mathrm{~A} 2$ pieces

13. MCB20 A

14. Drum as a water reservoir. 


\section{- Testing the propeller using variations in the rotation of the drive shaft}

This test uses variations in the number of teeth in order to obtain variations in rotation. The propeller shaft is connected to the motor shaft using a gear transmission. the number of gear teeth on the propeller shaft is $11,16,20$, and 22 . The schematic for this test is shown in Figure 4 .

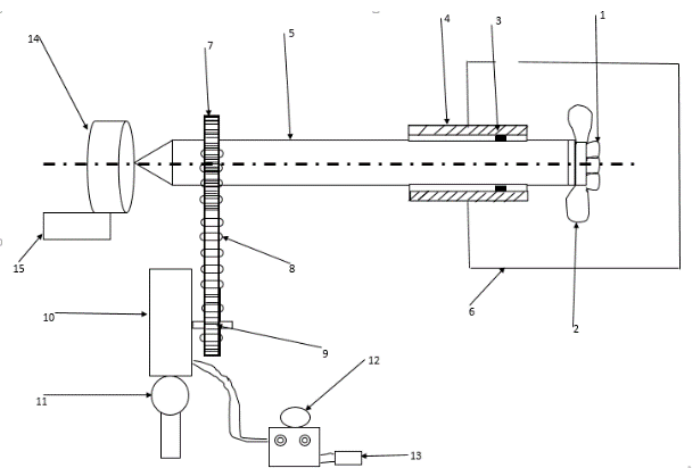

Figure 4 Schematic of Thrust Testing With Propeller Rotation Variations

\section{Picture description:}

1. Locking Bolt

2. Propeller with 4 variations

3. Bearings

4. Shaft guard

5. Shaft

6. Drum

7. Gear on propeller shaft with 2 variations

8. Chain

9. Gear on DCmotor

10. DCmotor

11. DCmotor mount

12. Battery $12 \mathrm{~V}, 70 \mathrm{~A} 2$ pieces

13. $\mathrm{MCB}$

14. Scales

15. Scales stand 


\section{RESULTS AND DISCUSSIONS}

\section{- Calculation of Shaft Diameter}

To connect the motor to the propeller shaft, it is necessary to calculate the strength of the shaft itself using the following equation $d=\sqrt[3]{\frac{16 . T}{\pi \bar{\tau}}}$ , where $P=\omega \times T$, then $T=\frac{p}{\omega}$,the power used is $=250$ Watt, by taking the design factor $(\mathrm{Pd})=1,2$ then $\mathrm{P}=300$ Watt, then the torque is $T=\frac{300 \mathrm{Nm} / \text { det }}{\left(\frac{2 \pi n}{60}\right)}=\frac{300 \mathrm{Nm} / \text { det }}{\left(\frac{2.3,14.2650}{60}\right)}=\frac{300 \mathrm{Nm} / \text { det }}{277,3 \mathrm{rad} / \mathrm{det}}=1,09 \mathrm{Nm}=1.090 \mathrm{Nmm}$, so we get $d=\sqrt[3]{\frac{16 \cdot T}{\pi \bar{\tau}}}=\sqrt[3]{\frac{16 \cdot 1090 N m m}{3,14 \cdot 45 N / m^{2}}}=\sqrt[3]{124} \mathrm{~mm}^{3}=5 \mathrm{~mm}$

Because the shaft has been reduced due to the installation of the pegs, in this test the diameter of the shaft used is $10 \mathrm{~mm}$.

\section{- Chain and Gear Analysis}

The rotation of the DC motor used is 2650 revolutions per minute with the number of gears is 11 pieces. The number of rotation reducers uses 4 gears, namely: $n_{1}=11$, $n_{2}=16, n_{3}=20, n_{4}=22$, using the equation: $n_{1} \times \alpha_{1}=n_{2} \times \alpha_{2}$

Where:

$n_{1}=$ rotation of the motor

$n_{2}=$ rotation on the propeller shaft using a 16 tooth gear

$n_{3}=$ rotation on the propeller shaft using a 20 tooth gear

$n_{4}=$ rotation on the propeller shaft using a 22 tooth gear

$\alpha_{1}=$ the number of gear teeth 11 pieces

$\alpha_{2}=$ the number of gear teeth 16 pieces

$\alpha_{3}=$ the number of gear teeth 20 pieces

$\alpha_{4}=$ the number of gear teeth 22 pieces

By using 11 pieces of gear, the rotation of the propeller is the same as the rotation of the driving motor, which is $2650 \mathrm{rpm}$.

By using 16 pieces of gear, the propeller rotation is as follows:

$n_{2}=\frac{n_{1} \propto_{1}}{\propto_{2}}=\frac{2650 \times 11}{16}=1821.8 \mathrm{rpm}$.

By using 20 pieces of gear, the propeller rotation is as follows:

$n_{3}=\frac{n_{1} \propto_{1}}{\propto_{3}}=\frac{2650 \times 11}{20}=1457.5 \mathrm{rpm}$.

By using 22 pieces of gear, the propeller rotation is as follows:

$n_{4}=\frac{n_{1} \propto_{1}}{\propto_{3}}=\frac{2650 \times 11}{22}=1325 \mathrm{rpm}$.

\section{- Testing (data collection)}

The propeller thrust test uses a series of propellers that are connected to the scales through a shaft so that when the propeller rotates, the shaft will be pushed into the scales so that the scales will experience pressure from the shaft. As shown in 
Figure 5 .

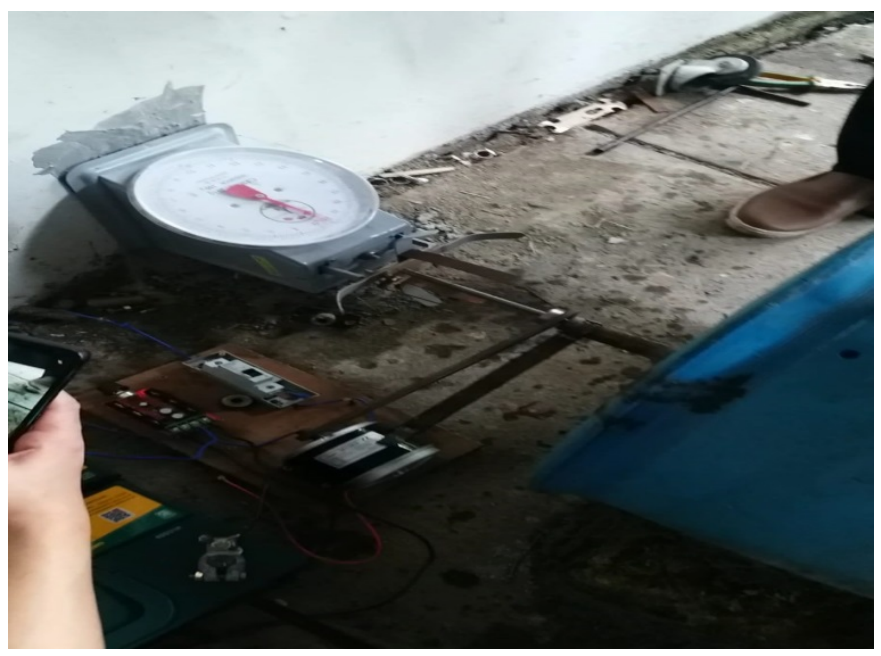

Figure 5 Testing The Thrust

From the test results obtained the following data:

\section{Table 1 Test Data Using Propeller Diameter Varia- tions}

\begin{tabular}{cccc}
\hline No & Diameter (mm) & Thrust (kgf) & Current(A) \\
\hline 1 & 17.5 & 14 & 38 \\
2 & 15.5 & 9 & 22 \\
3 & 14.8 & 7.5 & 9.2 \\
\hline 4 & 14.5 & 6 & 7.6 \\
\hline
\end{tabular}

Table 2 Test Data Using Propeller Rotation Variations

\begin{tabular}{cccc}
\hline No & Number of teeth & Thrust (kgf) & Current(A) \\
\hline 1 & 11 & 12 & 37 \\
2 & 16 & 8.5 & 24 \\
3 & 20 & 7,5 & 10 \\
4 & 22 & 6 & 8,5 \\
\hline
\end{tabular}

The number of teeth on the drive motor is 11 teeth.

\section{- Test chart}

From Figure 6 , the test graph using diameter variations shows that the larger the diameter of the propeller, the greater the amount of thrust and current, and vice versa. 


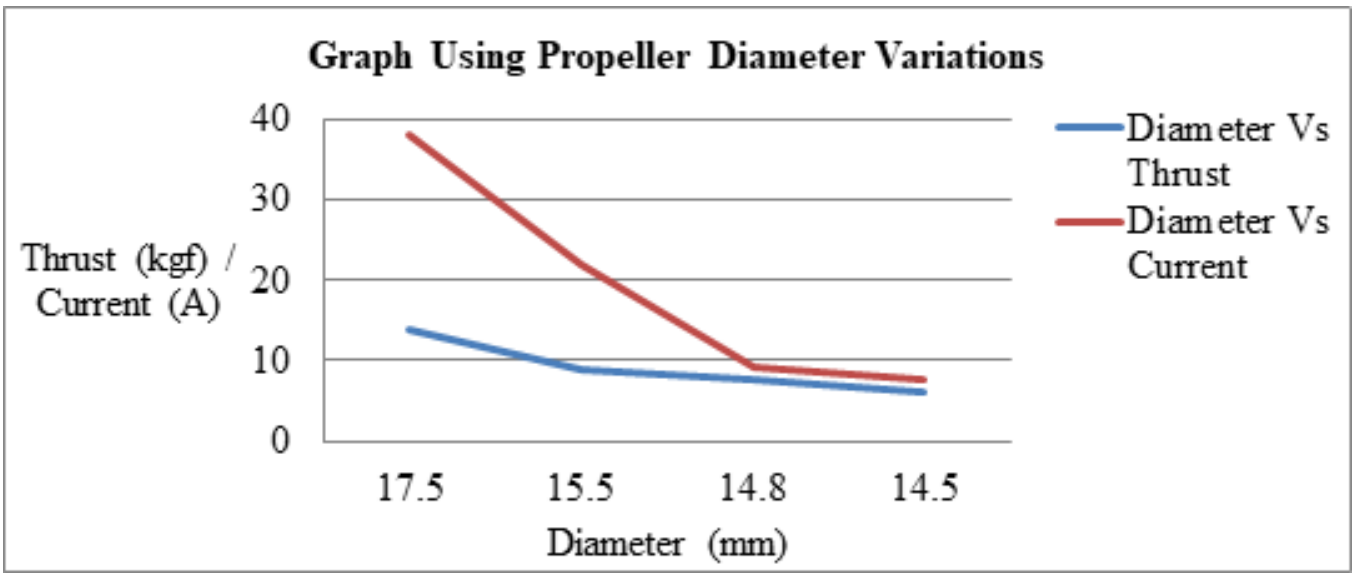

Figure 6 Graph Using Variations In The Diameter Of ThePropeller

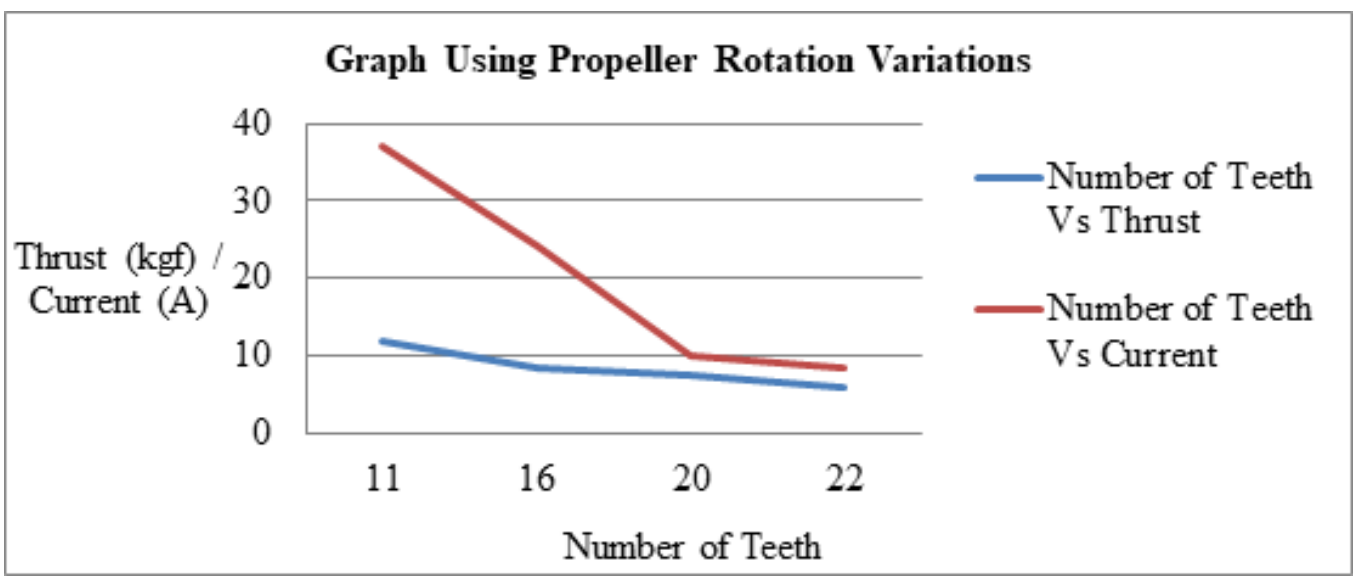

Figure 7 Test Graph Using Propeller Rotation Variations

From Figure 7 , the test graph using variations in the rotation of the drive shaft shows that the smaller the number of gear teeth, the greater the amount of thrust and current, and vice versa.

\section{CONCLUSIONS AND RECOMMENDATIONS}

From this study it was concluded that:

1. The larger the diameter of the propeller, the greater the thrust and the stronger the current.

2. An adequate variation of the diameter of the propeller is to use a diameter of 14.8 with a thrust of $7.5 \mathrm{kgf}$ and a current of $9.2 \mathrm{~A}$. This value meets the requirements because the current does not exceed $10 \mathrm{~A}$. 
3. The smaller the number of gear teeth, the greater the thrust and the stronger the current.

4. Adequate speed variation is to use the number of teeth 20 and a thrust of 7.5 $\mathrm{kg}$ while the current is 10 .

Suggestions from researchers:

1. It is hoped that other researchers will apply the research directly.

2. If applied, it is better not to use rotation variations because the use of chains often uses problems (chains are separated from gear).

\section{REFERENCES}

Amin. (2017). "Inilah 7 Keunggulan Solar Cell Sebagai Sumber Energi Masa Depan,".

Elinur. (2010). Perkembangan Konsumsi Dan Penyediaan Energi Dalam Perekonomian Indonesia. Indones. J. Agric. Econ, 2(1).

Rojali, I. (2019). "Analisa Kemampuan Thrust Dan Kecepatan Kapal Berdasarkan Variasi Diameter Propeller Menggunakan Metode CFD Pada Kapal Perintis 1200 GT," Politeknik Perkapalan Negeri Surabaya,.

Samosir, R. (2021). "DESIGN, BUILD, AND TESTING TRANSPORTATION WHEELS FOR TRANSPORTATION OF PALM OIL FRUIT IN PEATLAND,.. 9(5), 49-55. Retrieved from Https://Granthaalayahpublication.Org/Journals/Index.Php/Granthaalayah/Article/ View/3887 